\title{
Illustrations for Leggende croate
}

This section presents facsimiles of the original illustrations by Carlo Galleni and by David Baffetti made for the 1957 Italian edition of Croatian Tales of Long Ago (Leggende croate) by Ivana Brlić-Mažuranić. The title Favole antiche was also considered, but it was eventually abandoned.

The original plates are preserved in the Giunti Historical Archive, Images collection, Folder 443. The folder contains original plates and proofs for the best solutions in printing the book. All these facsimiles are published in Leggende croate, translated from Croatian into Italian by Umberto Urbani and published in Florence by Marzocco.

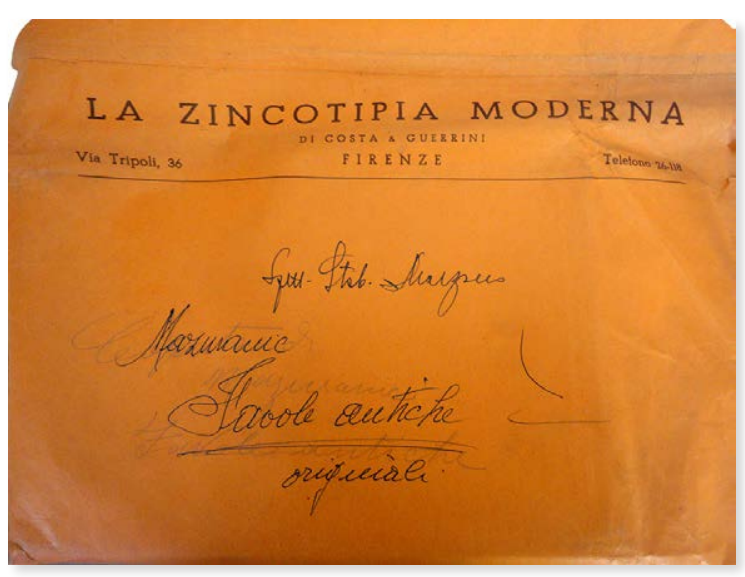

The envelope containing the file with original illustrations by Carlo Galleni and David Baffetti.

Omotnica s mapom koja sadrži izvorne ilustracije Carla Gallenija i Davida Baffettija.
Carlo Galleni (1920 - 2015) was a Florentine artist. In 1936, when he was only sixteen years old, he illustrated an edition of the Bible by the Florence children's literature publisher Salani. In the following years he illustrated fairy tales by Emma Perodi, Charles Perrault and Madame de Segur in the Salani editions and in 1948 in the Mondadori edition of Enciclopedia dei ragazzi [Young People's Encyclopaedia]. In the Marzocco editions in 1953 he illustrated Peter Pan, some fairy tales and historical novels.

David Baffetti (?) was a Florentine architect. We have limited biographical information about him. In 1933 he illustrated I racconti di Boscobello [The Stories of Boscobello] by Bruna Bini. In the following years he worked as a curator of exhibitions, including Fernando Farulli: scene e costumi per Ulisse [Fernando Farulli: Sets and Costumes for Ulysses] (1969), La ceramica di Montelupo [Ceramics from Montelupo] (1970), and History Today (Museum of the City of Skopje, 1994). ${ }^{1}$

Sabrina Fava

\footnotetext{
1 We are grateful to the Giunti Historical Archive in Florence and to its Director, Dr. Aldo Cecconi, for giving Libri \& Liberi permission to publish the facsimiles of the original illustrations by Carlo Galleni and by David Baffetti made for the 1957 Italian edition of Croatian Tales of Long Ago (Leggende croate) by Ivana Brlić-Mažuranić, in both printed and electronic versions of this issue.
} 


\section{Ilustracije za Leggende croate}

Ovdje donosimo faksimile originalnih ilustracija Carla Gallenija i Davida Baffettija koje su načinjene za talijansko izdanje Priča iz davnine Ivane BrlićMažuranić, koje je 1957. objavljeno pod naslovom Leggende croate. Također se razmatrao i naslov Favole antiche, no od njega se na kraju odustalo.

Izvorni se crteži i slike čuvaju u Povijesnome arhivu „Giunti“ (Zbirka slika. Mapa 443). Mapa sadrži originalne table i pripadne otiske načinjene kako bi se odabralo najbolje rješenje za tisak. Svi su ti faksimili kasnije uvršteni u spomenuto izdanje Leggende croate, u prijevodu Umberta Urbanija, a knjiga je objavljena u

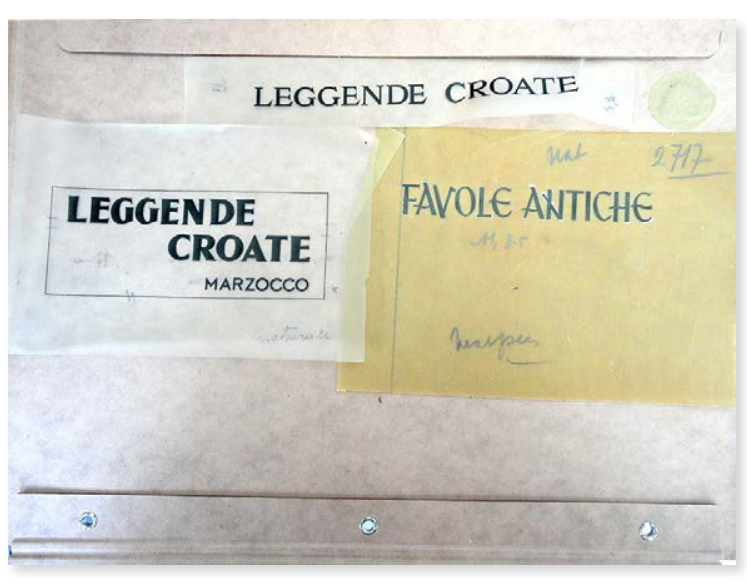

Printing proofs for the book. In this step the title Favole antiche becomes Leggende croate.

Priprema za tisak knjige. U ovome se koraku umjesto naslova Favole antiche prihvatio naslov Leggende croate. nakladi Marzocca iz Firence.

Carlo Galleni (1920.-2015.) bio je firentinski umjetnik. Kad je imao samo šesnaest godina, 1936., oslikao je izdanje Biblije firentinskoga nakladnika dječjih knjiga, Salanija. Sljedećih je godina ilustrirao bajke Emme Perodi, Charlesa Perraulta i Madame de Segur za istoga nakladnika, a 1948. godine i djelo Enciclopedia dei ragazzi [Dječja enciklopedija], u Mondadorijevu izdanju. Za Marzoccovu nakladu 1953. godine ilustrirao je Petra Pana, pojedine bajke i povijesne romane.

David Baffetti (?) bio je firentinski arhitekt. Raspolažemo samo njegovim ograničenim biografskim podatcima. Zna se da je 1933. godine ilustrirao knjigu I racconti di Boscobello [Boscobellove priče] Brune Bini, a sljedećih je godina kao kustos postavio nekoliko izložbi, među kojima su: Fernando Farulli: scene e costumi per Ulisse [Fernando Farulli: scenografija i kostimi za Uliksa] (1969.), La ceramica di Montelupo [Keramika iz Montelupa] (1970.) i History Today [Povijest danas] (Muzej grada Skopja, 1994.). ${ }^{2}$

Sabrina Fava

\footnotetext{
2 Zahvaljujemo Povijesnomu arhivu „Giunti“ u Firenci i njegovu ravnatelju, doktoru Aldu Cecconiju, na suglasnosti da u tiskanome i elektroničkome izdanju ovoga broja časopisa Libri \& Liberi objavimo faksimile izvornih ilustracija Carla Gallenija i Davida Baffettija načinjene za talijansko izdanje Priča iz davnine (Leggende croate) Ivane Brlić-Mažuranić iz 1957. godine.
} 


\section{Illustrations by Carlo Galleni}
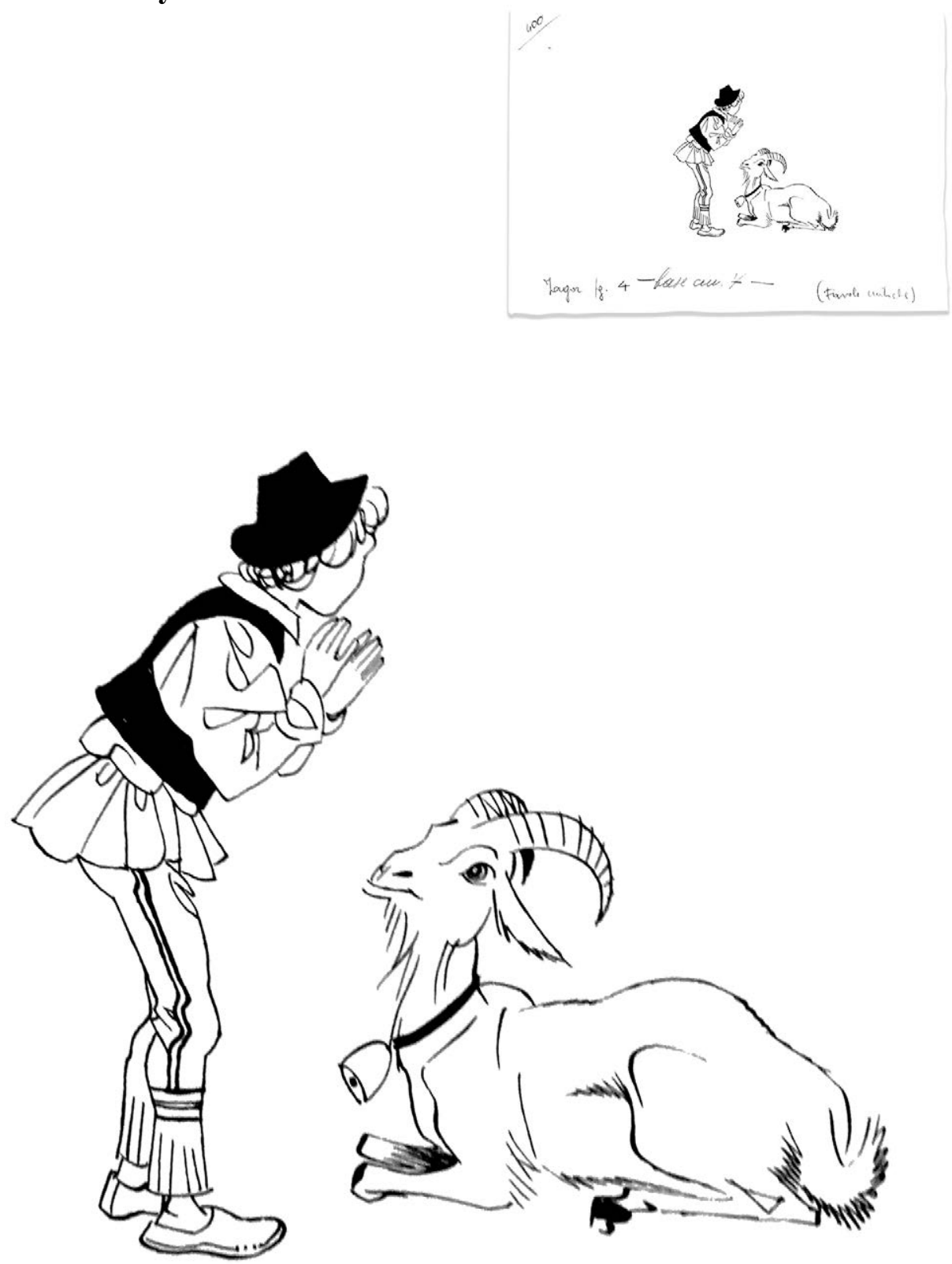

Carlo Galleni. An illustration for the story "Jagor".

Carlo Galleni. Ilustracija za priču ,Jagor“.

Published in / objavljeno u: Leggende croate (Brlić-Mažuranić 1957: 13). 


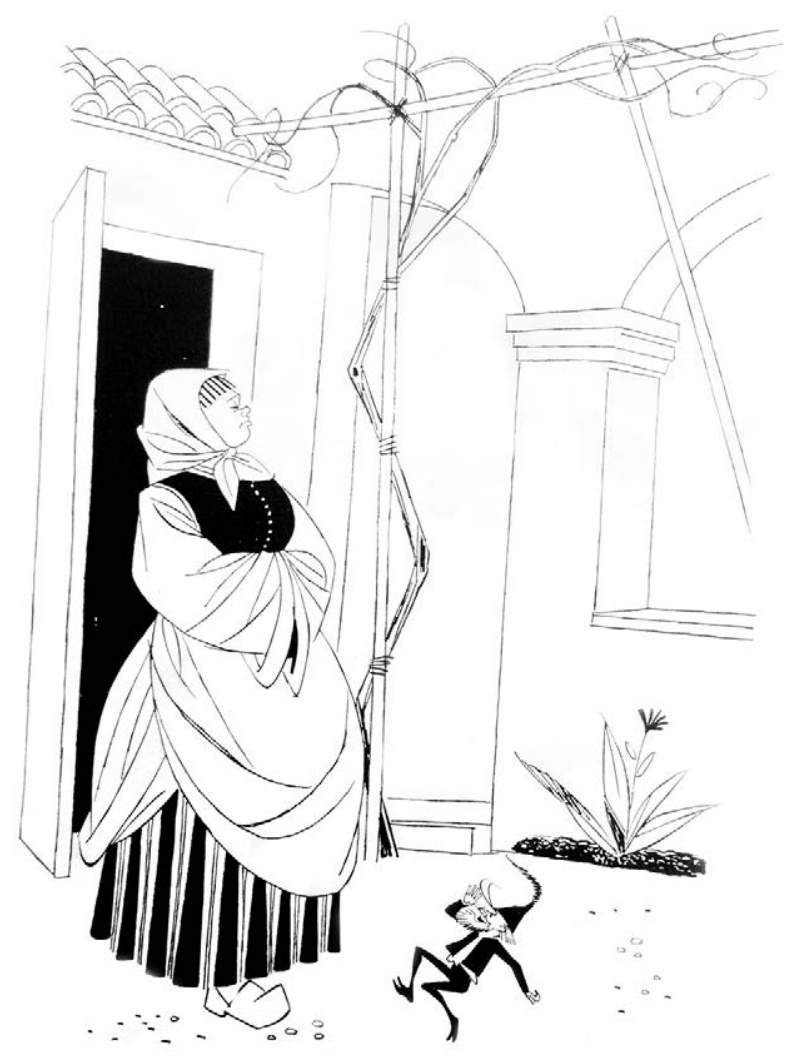

Carlo Galleni. An illustration for the story "Jagor".

Carlo Galleni. Ilustracija za priču ,Jagor“.

Published in / objavljeno u: Leggende croate (Brlić-Mažuranić 1957: 23). 

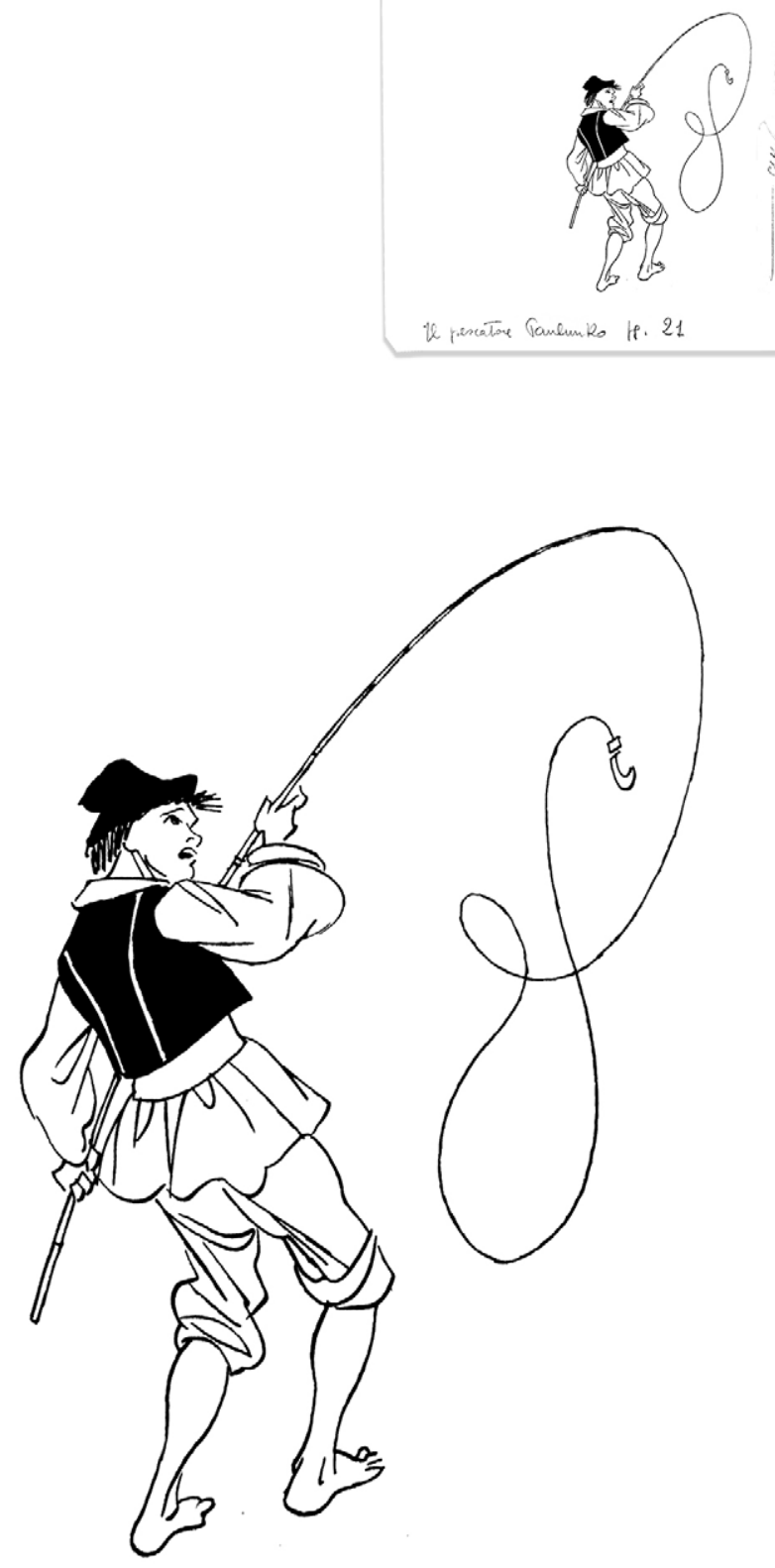

Carlo Galleni. An illustration for the story "Fisherman Plunk and His Wife".

Carlo Galleni. Ilustracija za priču „Ribar Palunko i njegova žena“.

Published in / objavljeno u: Leggende croate (Brlić-Mažuranić 1957: 31). 

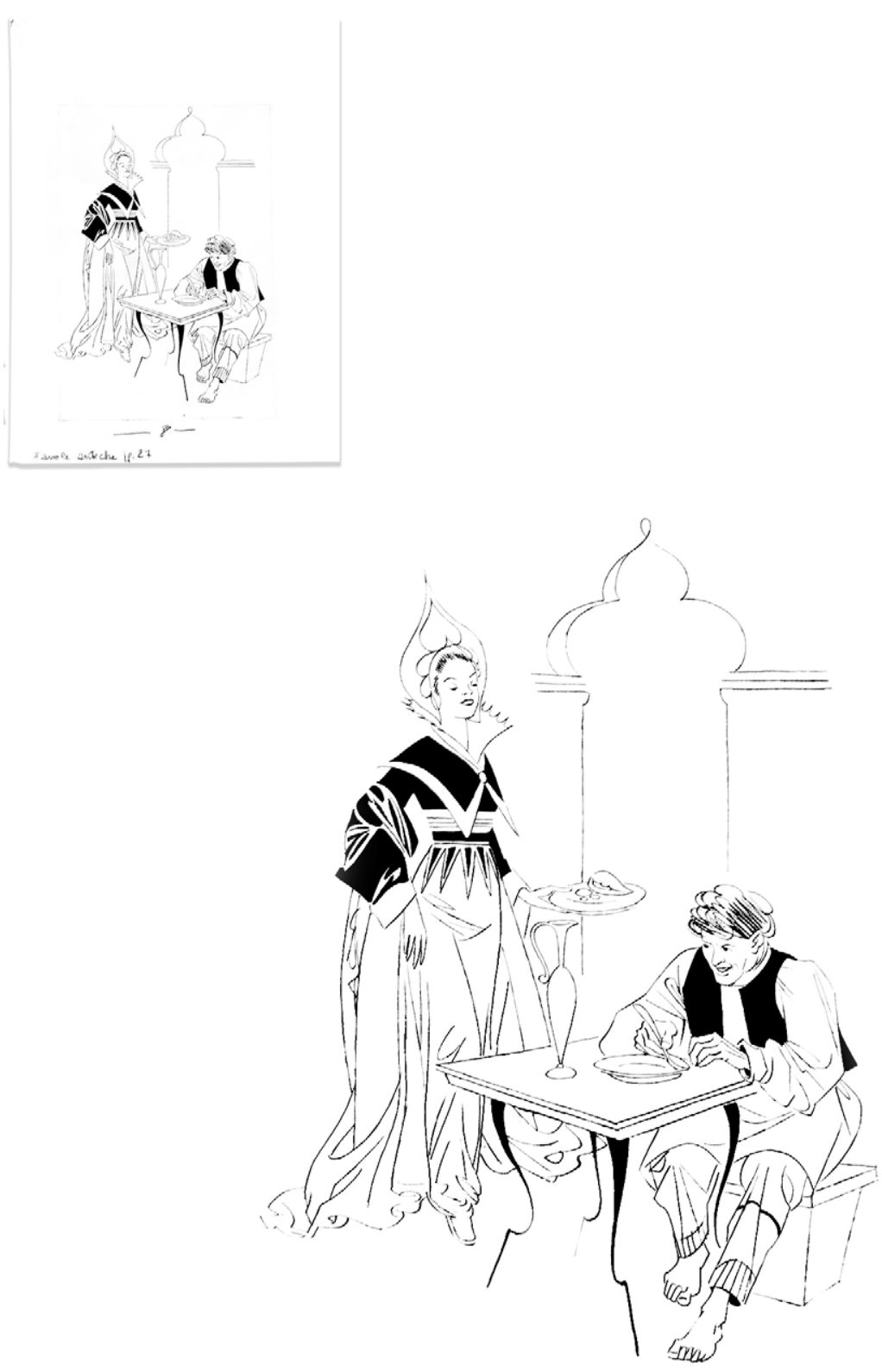

Carlo Galleni. An illustration for the story "Fisherman Plunk and His Wife".

Carlo Galleni. Ilustracija za priču „Ribar Palunko i njegova žena“.

Published in / objavljeno u: Leggende croate (Brlić-Mažuranić 1957: 40). 


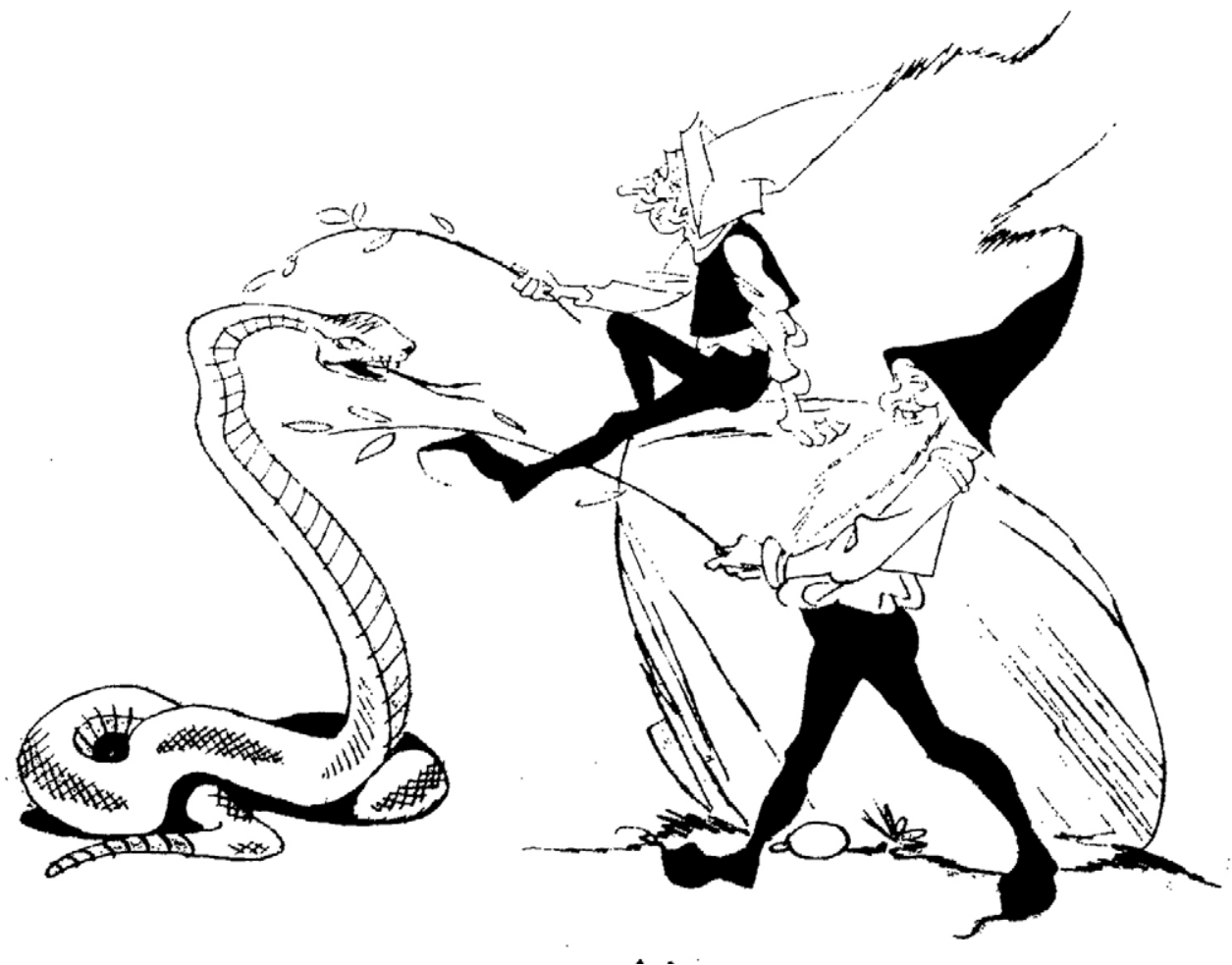

Carlo Galleni. An illustration for the story "Stribor's Forest".

Carlo Galleni. Ilustracija za priču „Šuma Striborova“.

Published in / objavljeno u: Leggende croate (Brlić-Mažuranić 1957: 55). 

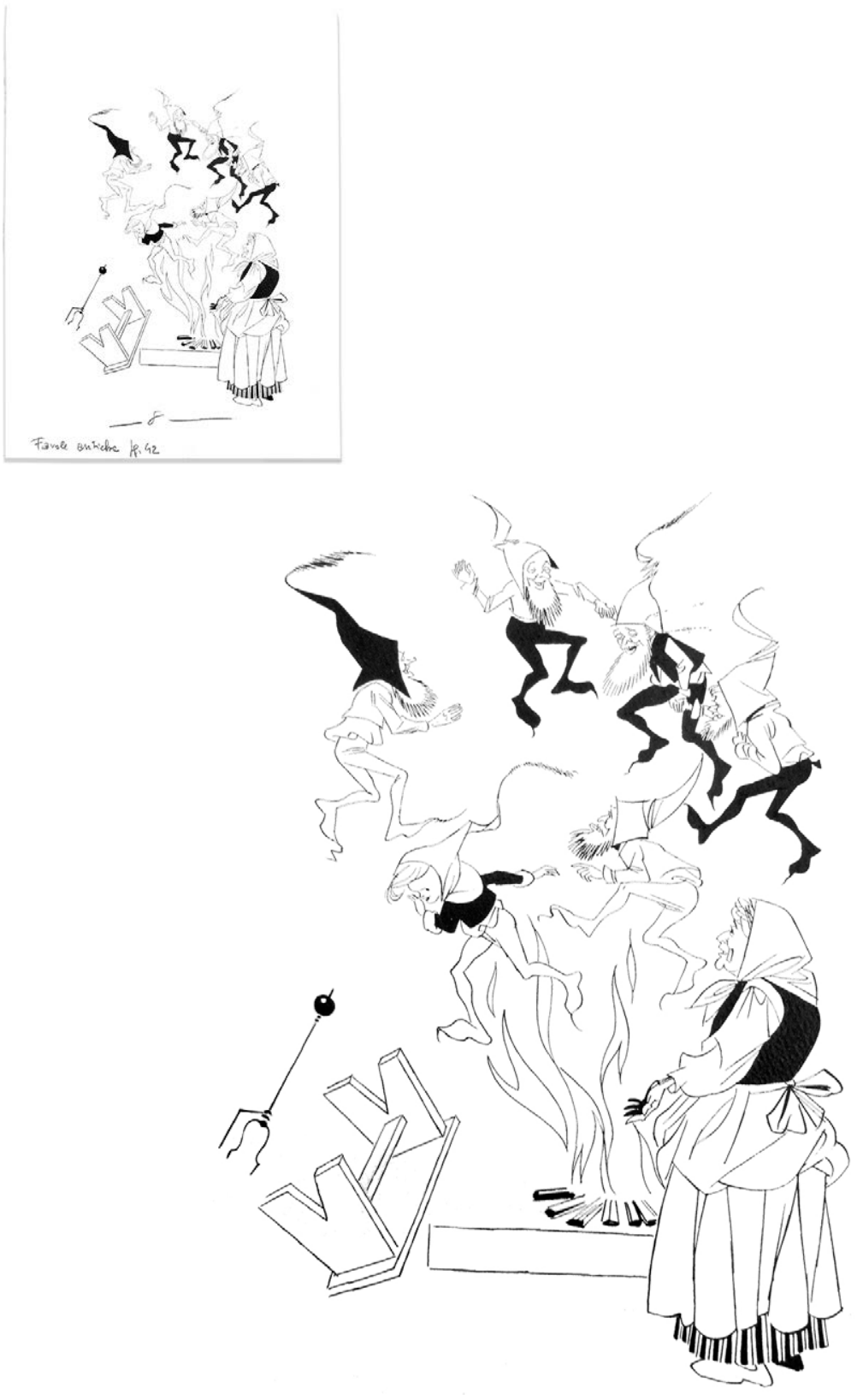

Carlo Galleni. An illustration for the story "Stribor's Forest".

Carlo Galleni. Ilustracija za priču „Šuma Striborova“.

Published in / objavljeno u: Leggende croate (Brlić-Mažuranić 1957: 66). 

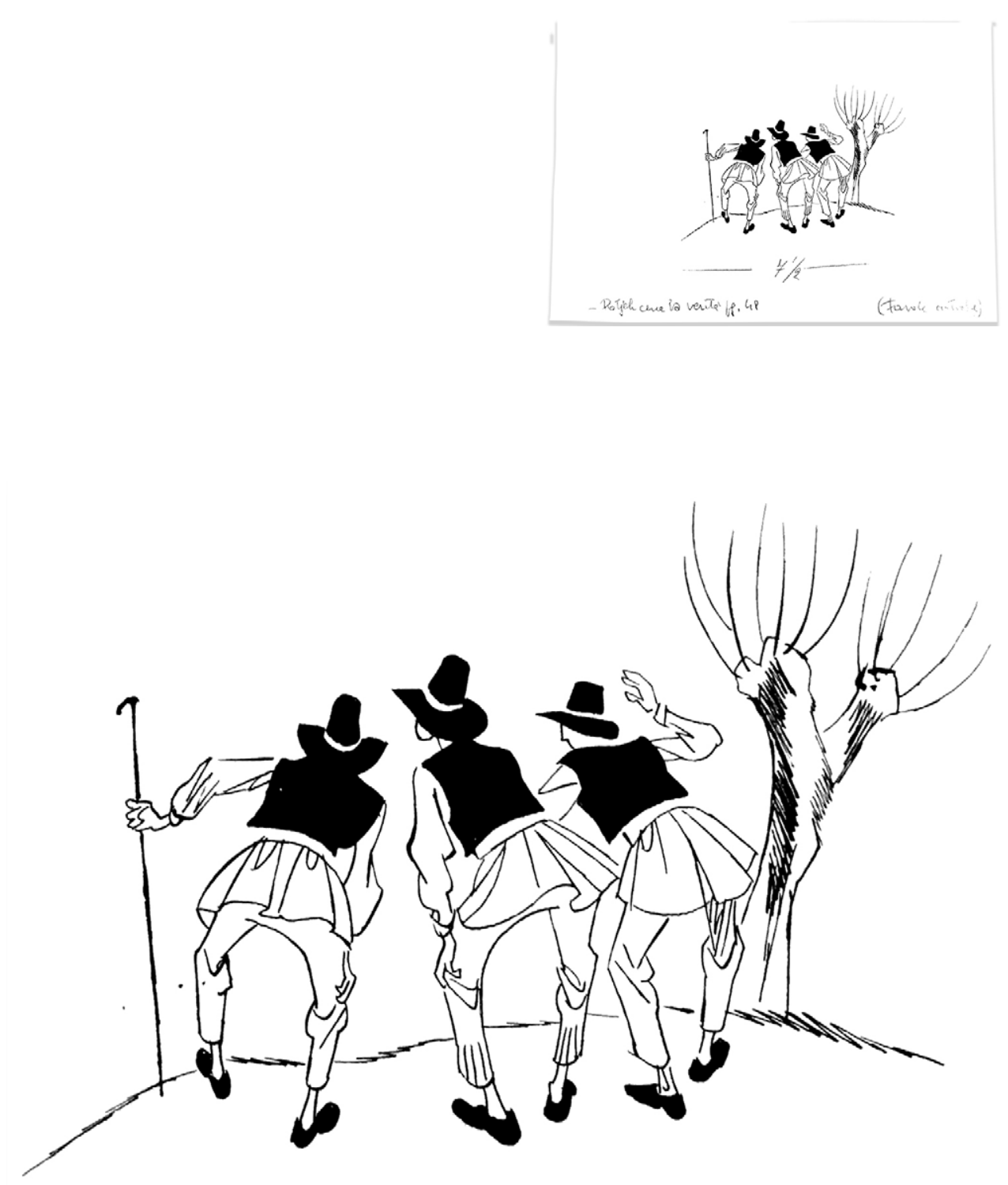

Carlo Galleni. An illustration for the story "How Quest Sought the Truth". Carlo Galleni. Ilustracija za priču „Kako je Potjeh tražio istinu“. Published in / objavljeno u: Leggende croate (Brlić-Mažuranić 1957: 69). 

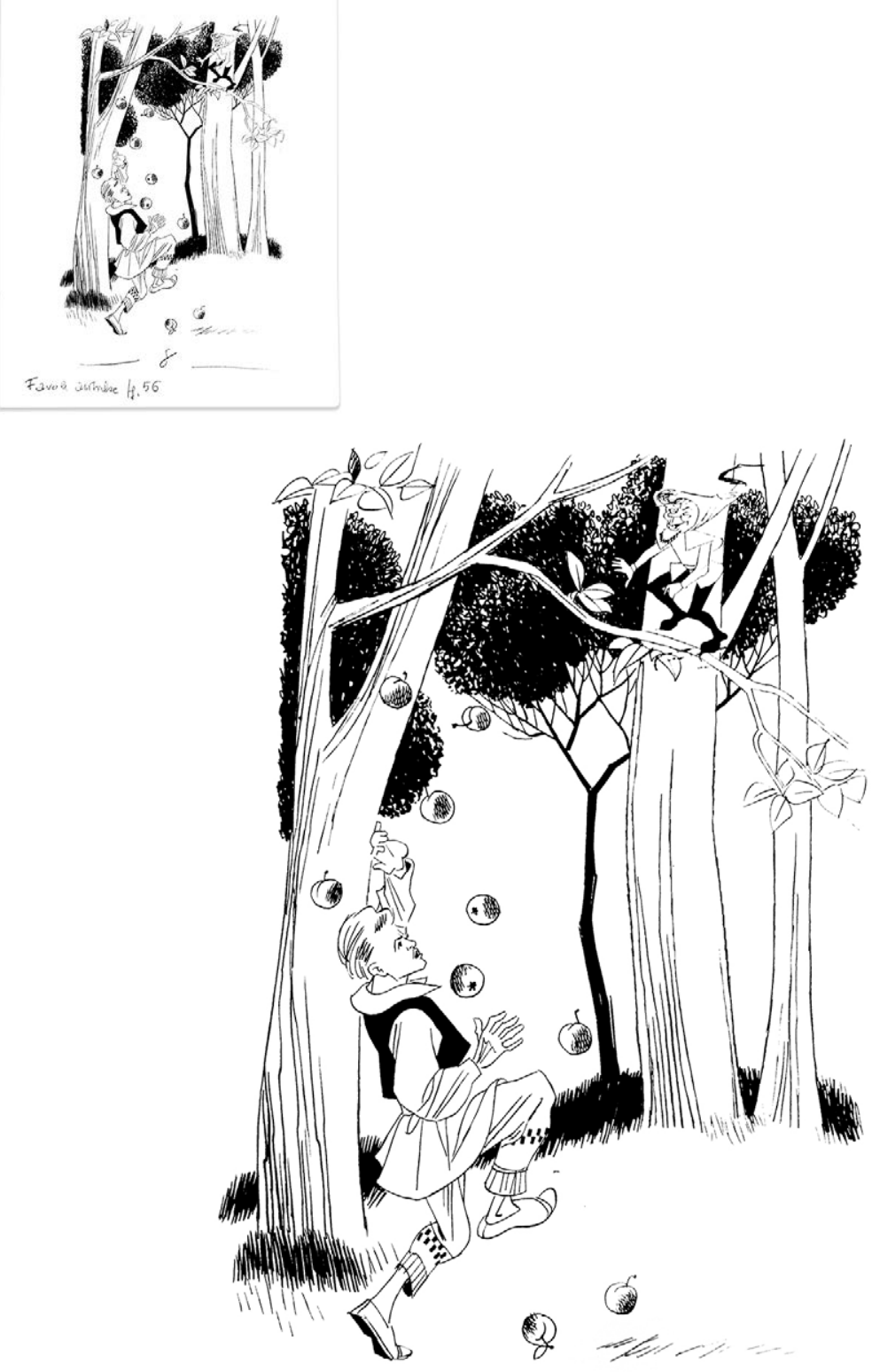

Carlo Galleni. An illustration for the story "How Quest Sought the Truth".

Carlo Galleni. Ilustracija za priču „Kako je Potjeh tražio istinu“.

Published in / objavljeno u: Leggende croate (Brlić-Mažuranić 1957: 80). 

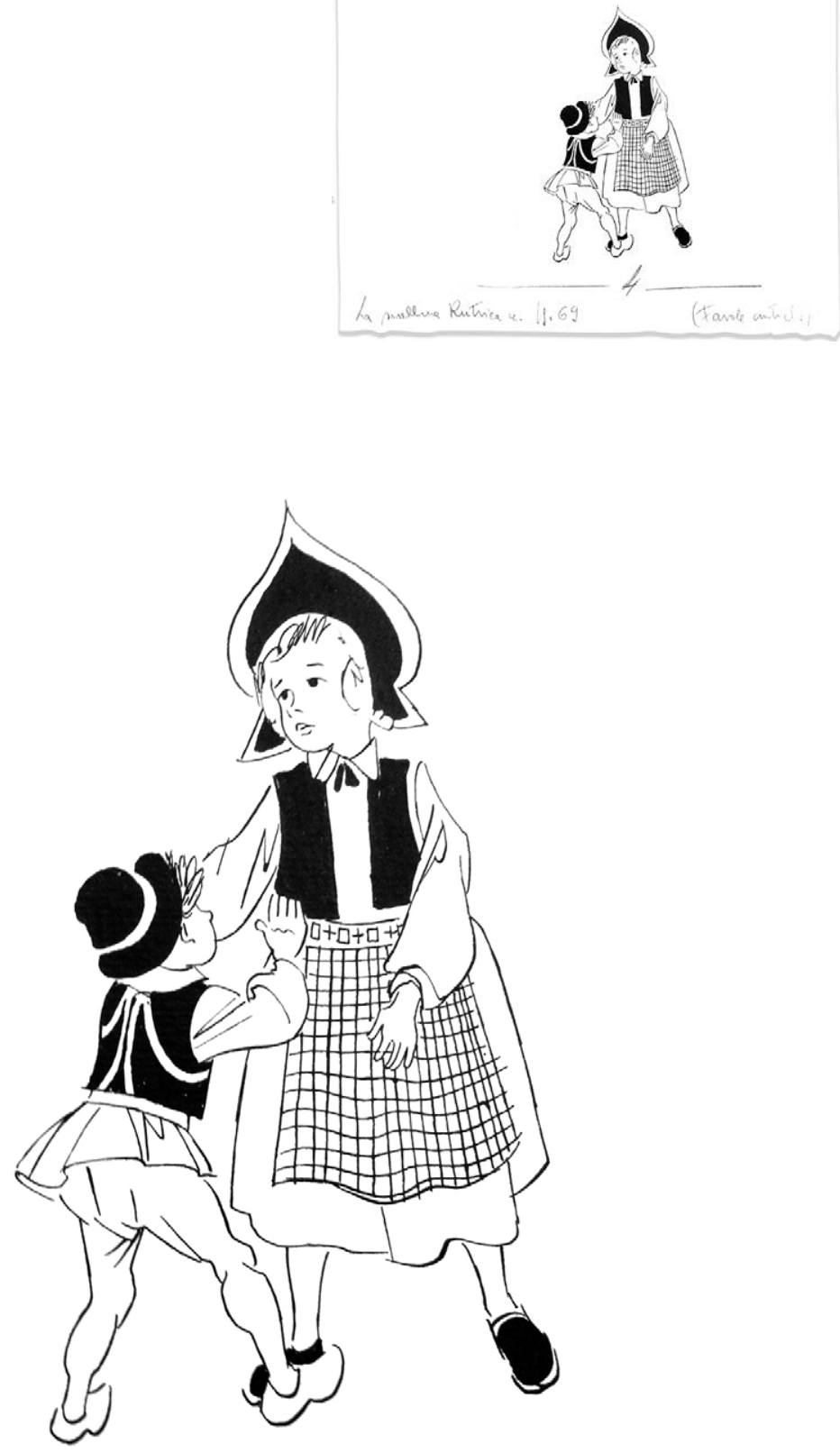

Carlo Galleni. An illustration for the story "Little Brother Primrose and Sister Lavender".

Carlo Galleni. Ilustracija za priču „Bratac Jaglenac i sestrica Rutvica“.

Published in / objavljeno u: Leggende croate (Brlić-Mažuranić 1957: 97). 

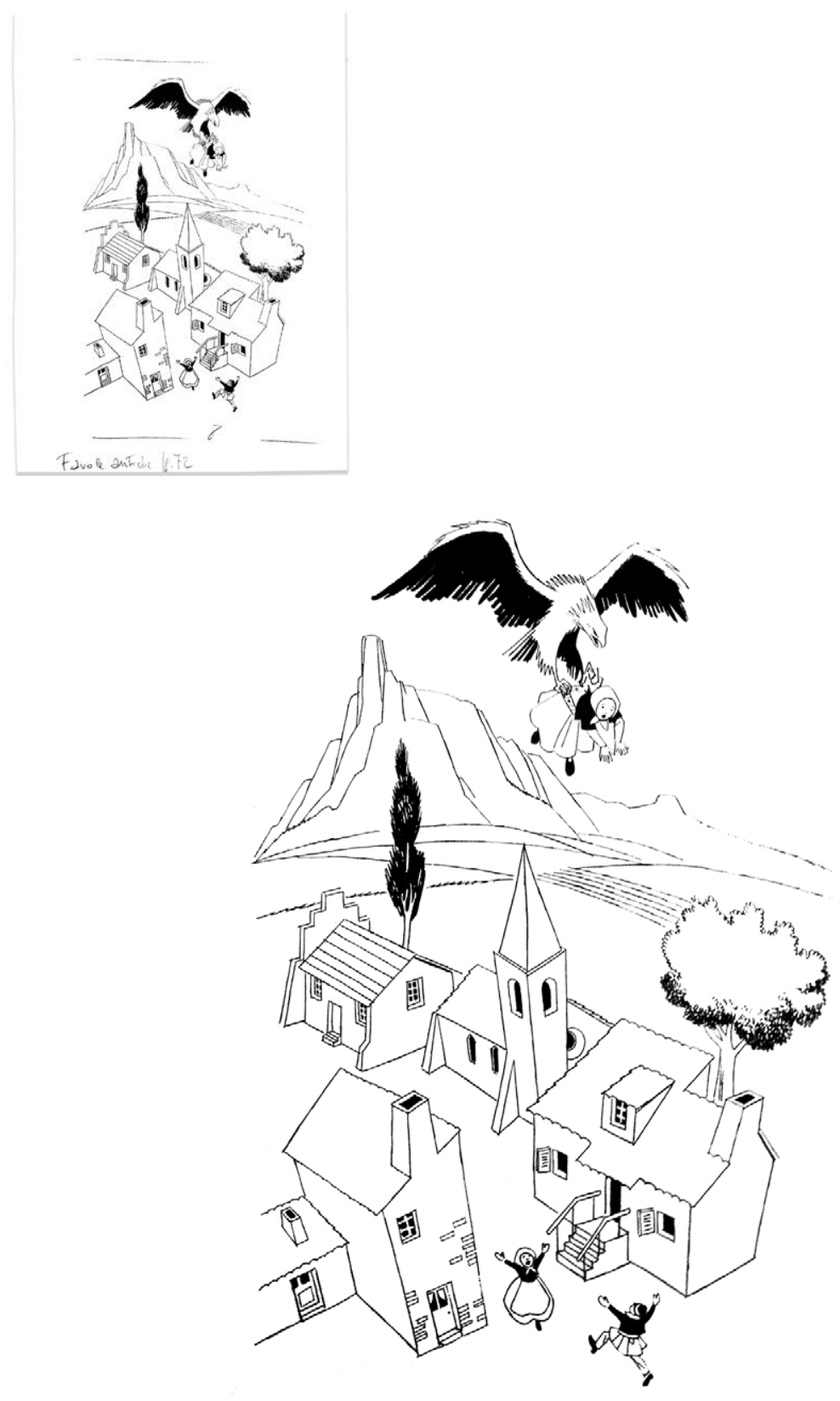

Carlo Galleni. An illustration for the story "Little Brother Primrose and Sister Lavender".

Carlo Galleni. Ilustracija za priču „Bratac Jaglenac i sestrica Rutvica“. Published in / objavljeno u: Leggende croate (Brlić-Mažuranić 1957: 101). 

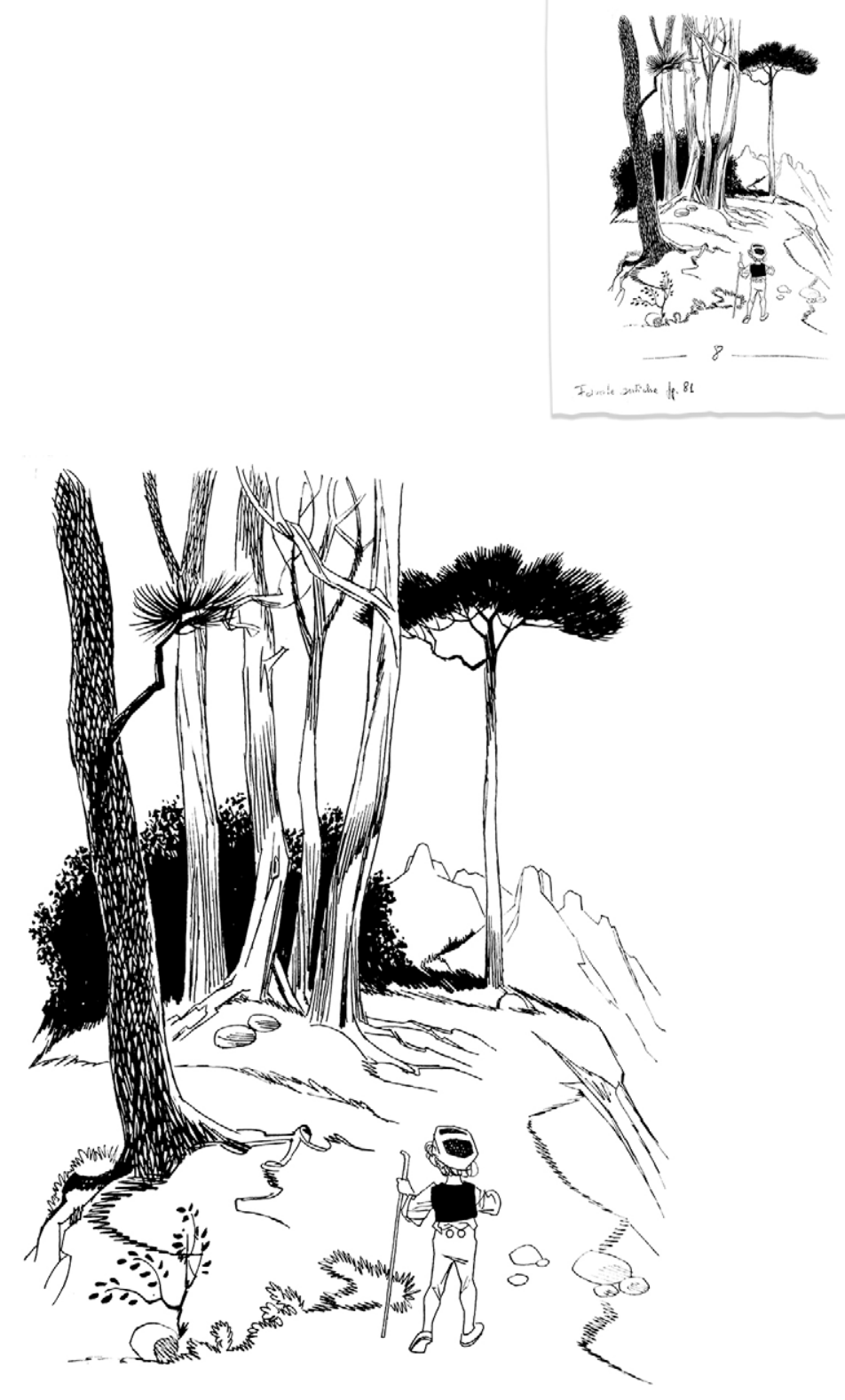

Carlo Galleni. An illustration for the story "Little Brother Primrose and Sister Lavender".

Carlo Galleni. Ilustracija za priču „Bratac Jaglenac i sestrica Rutvica“.

Published in / objavljeno u: Leggende croate (Brlić-Mažuranić 1957: 113). 


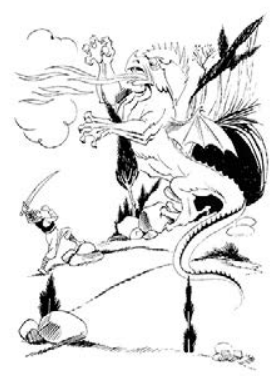

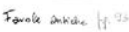

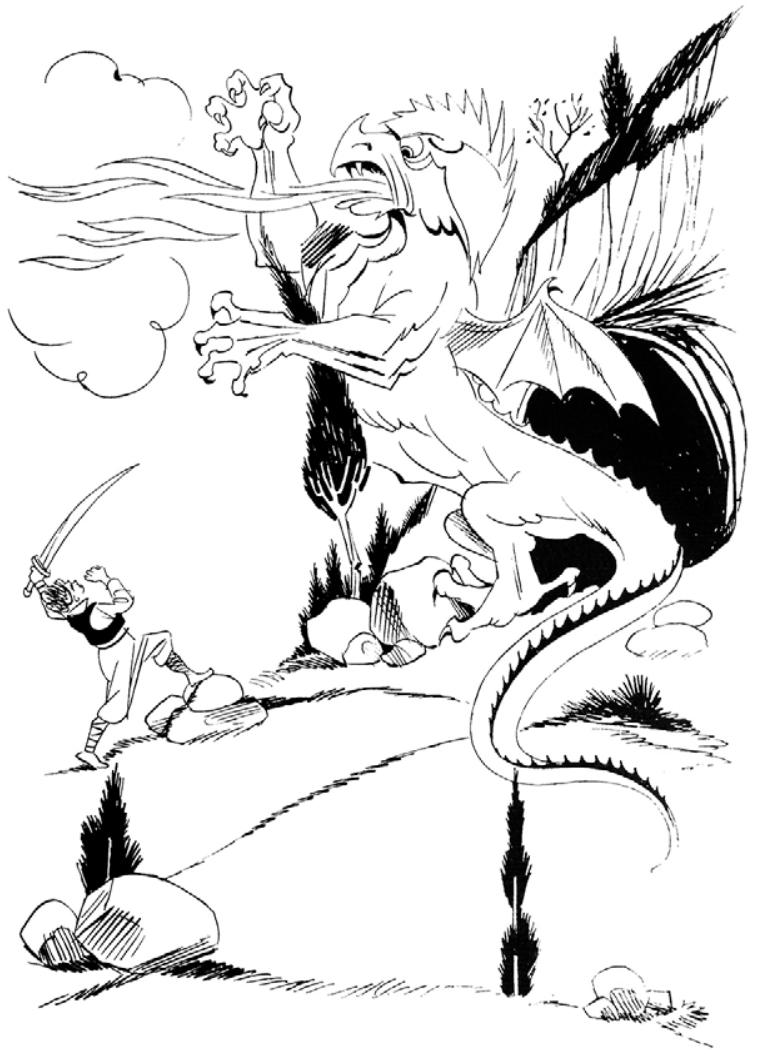

Carlo Galleni. An illustration for the story "Little Brother Primrose and Sister Lavender".

Carlo Galleni. Ilustracija za priču „Bratac Jaglenac i sestrica Rutvica“. Published in / objavljeno u: Leggende croate (Brlić-Mažuranić 1957: 129). 


\section{Illustrations by David Baffetti}

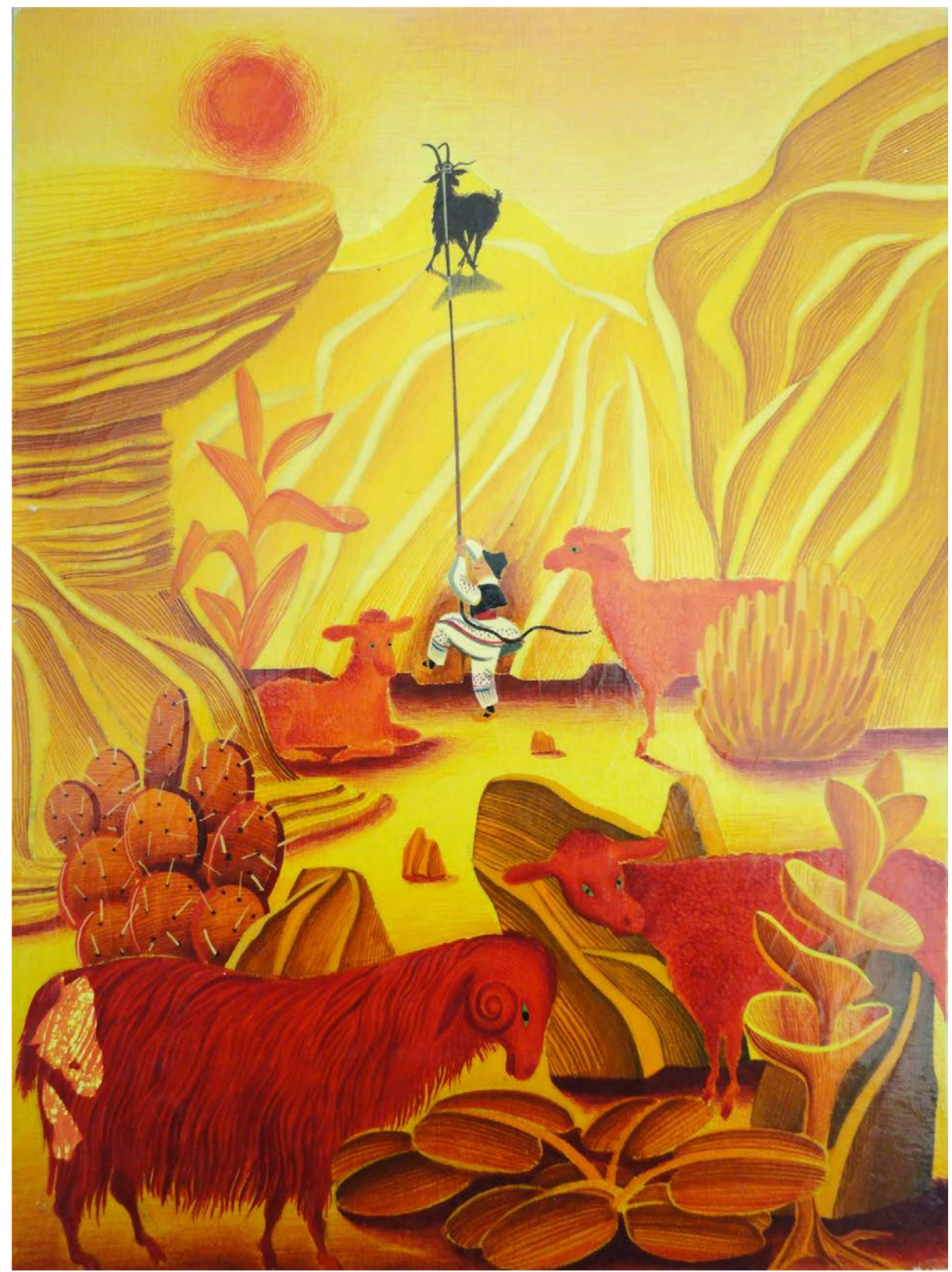

David Baffetti. An illustration for the story "Jagor".

David Baffetti. Ilustracija za priču „Jagor“.

Published in / objavljeno u: Leggende croate (Brlić-Mažuranić 1957: 21). 


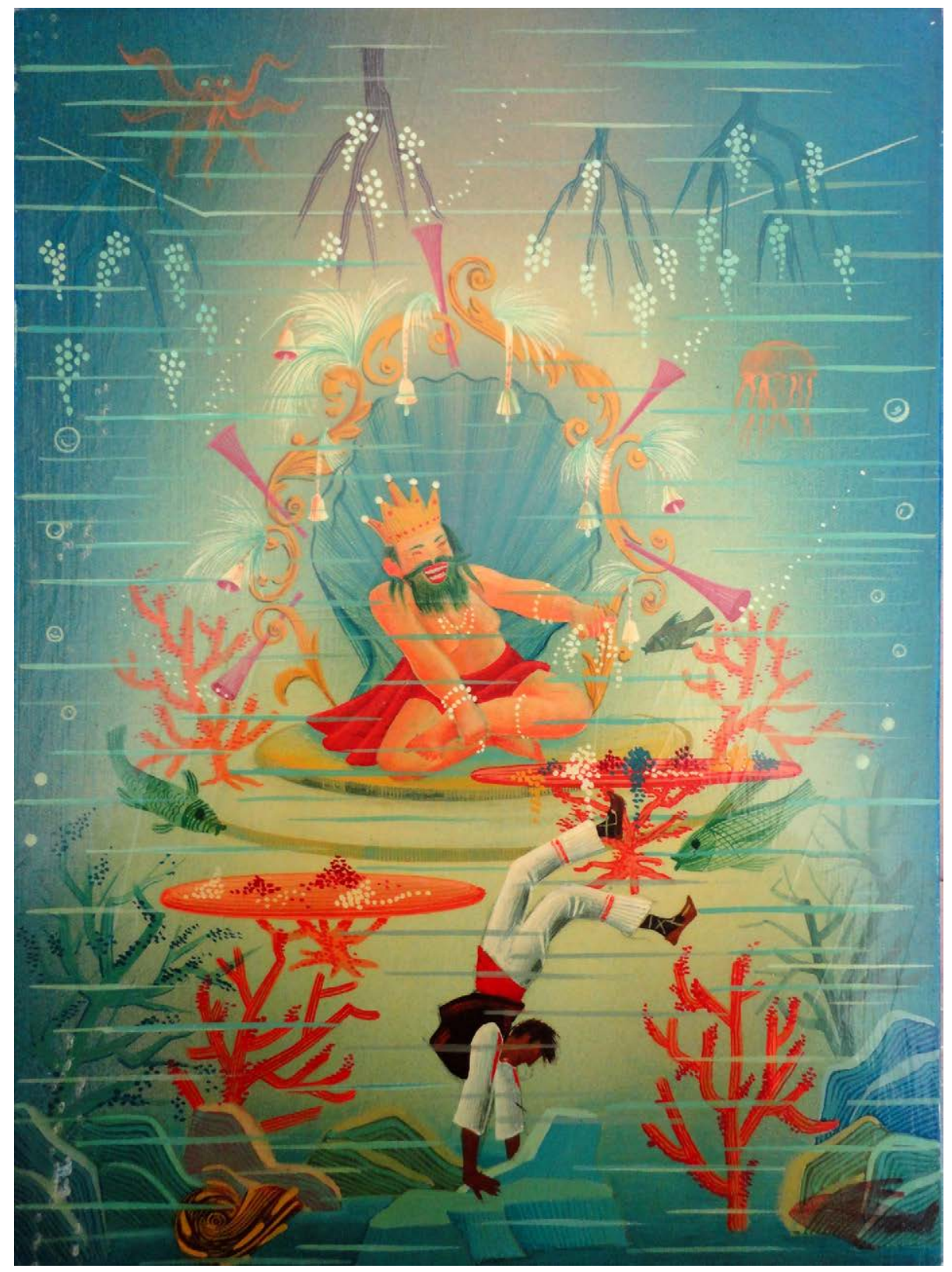

David Baffetti. An illustration for the story "Fisherman Plunk and His Wife". David Baffetti. Ilustracija za priču „Ribar Palunko i njegova žena“.

Published in / objavljeno u: Leggende croate (Brlić-Mažuranić 1957: 41). 


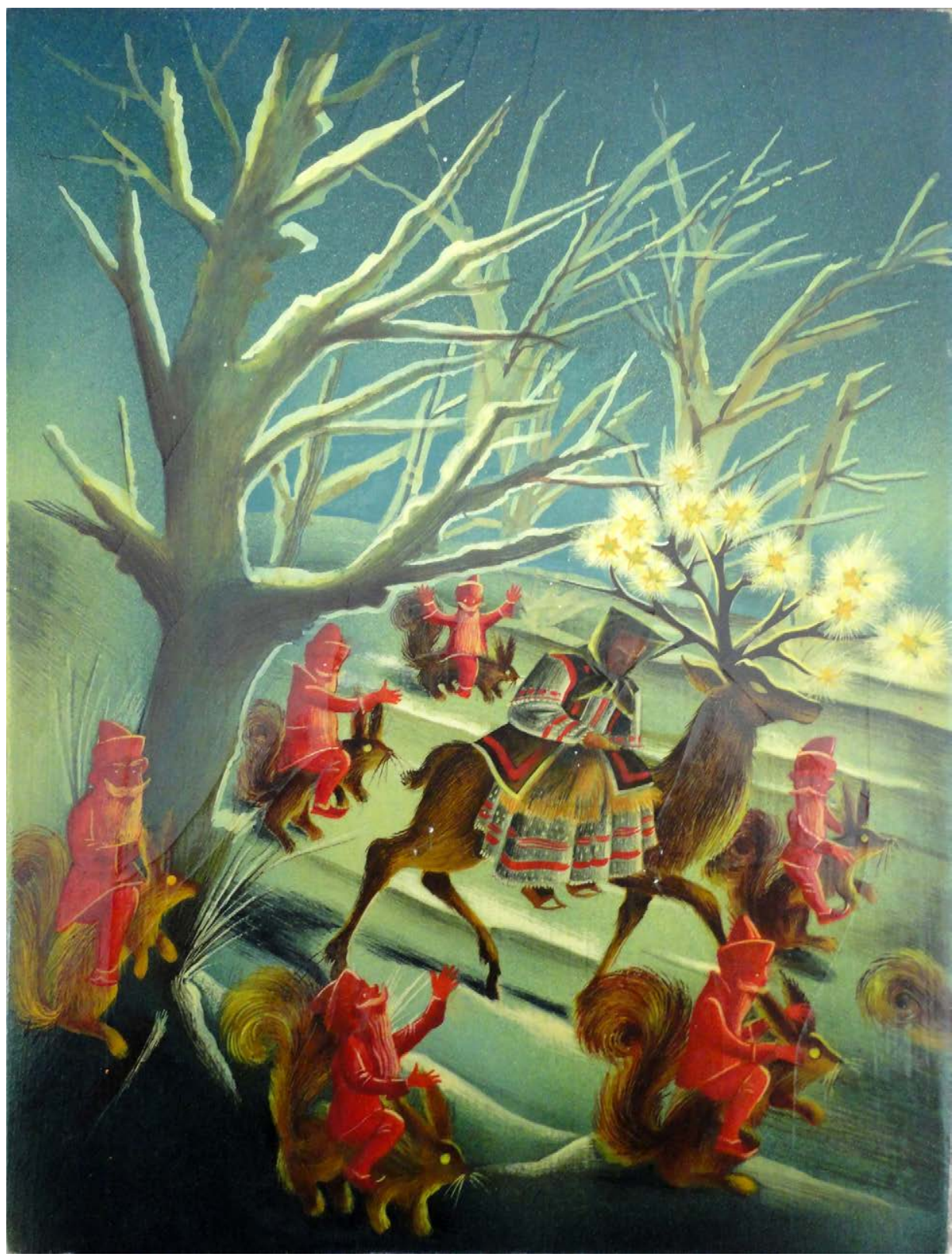

David Baffetti. An illustration for the story "Stribor's Forest".

David Baffetti. Ilustracija za priču „Šuma Striborova“.

Published in / objavljeno u: Leggende croate (Brlić-Mažuranić 1957: 61). 


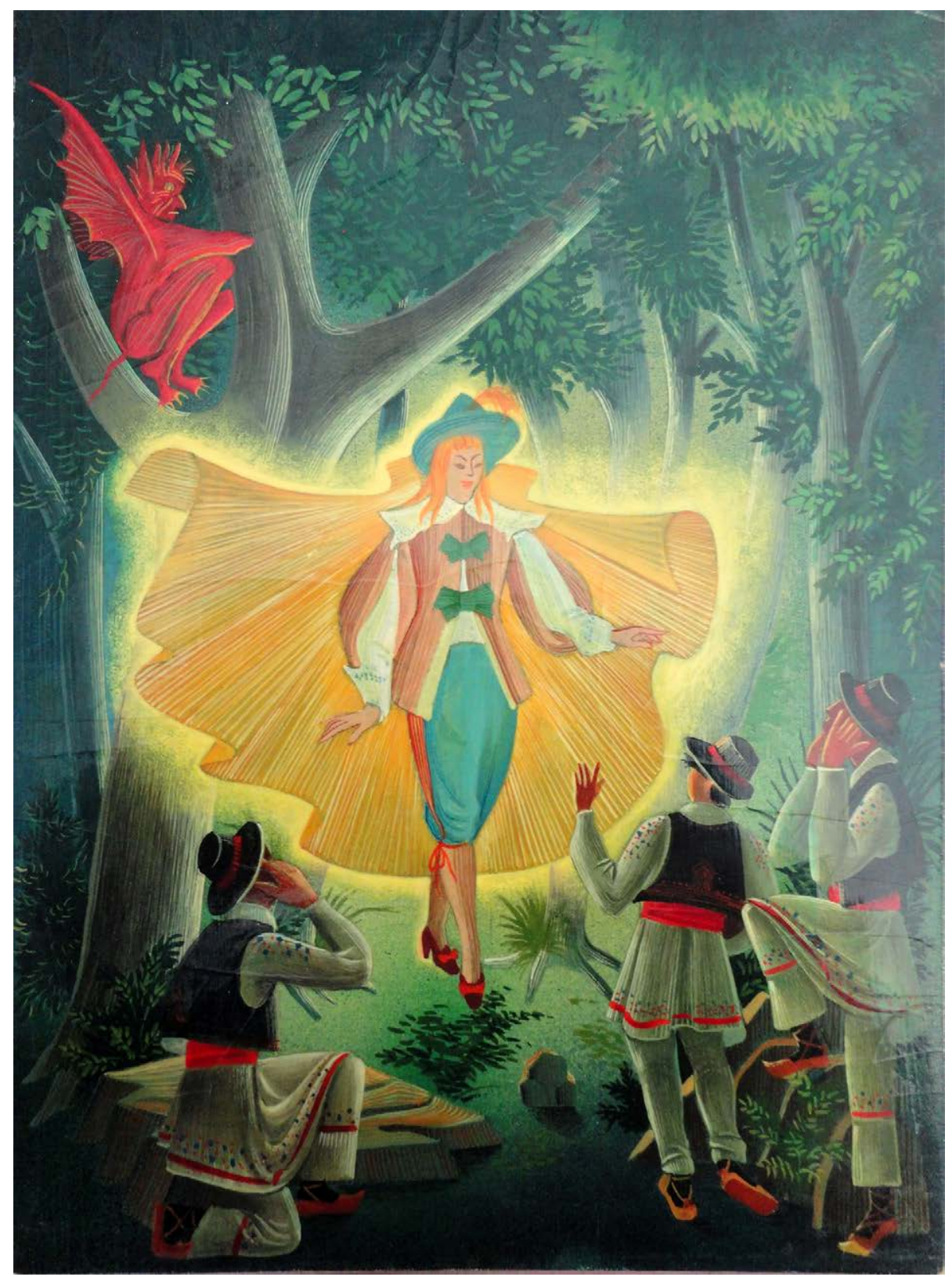

David Baffetti. An illustration for the story "How Quest Sought the Truth". David Baffetti. Ilustracija za priču „Kako je Potjeh tražio istinu“. Published in / objavljeno u: Leggende croate (Brlić-Mažuranić 1957: 81). 

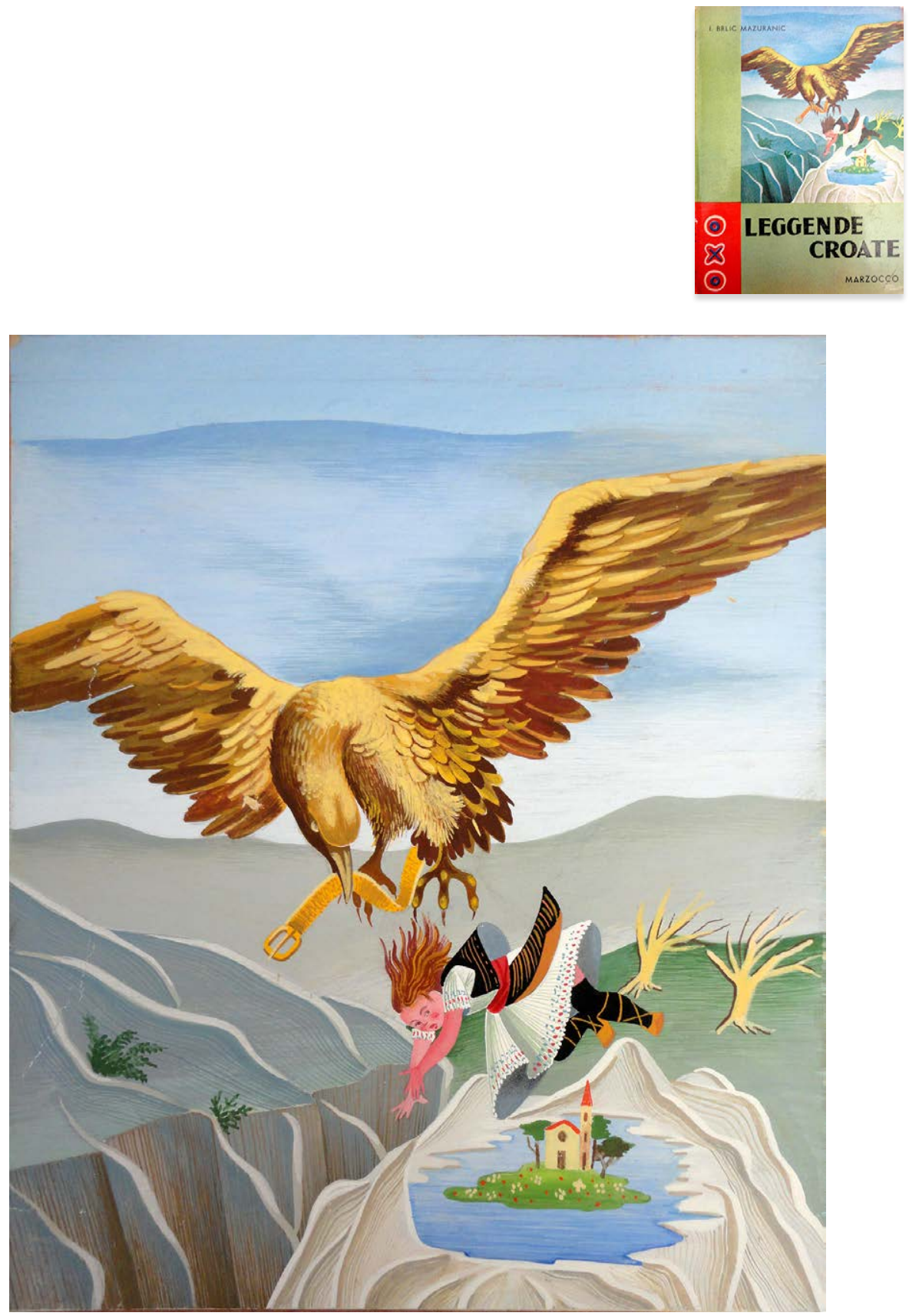

David Baffetti. An illustration for the story "Little Brother Primrose and Sister Lavender".

David Baffetti. Ilustracija za priču „Bratac Jaglenac i sestrica Rutvica“. Published on the front cover of / objavljeno na prednjoj strani korica knjige Leggende croate (Brlić-Mažuranić 1957). 


\section{JVANA BRTiĆ MAZ̃URAVIĆ:
PRICEIZDAVNINE}

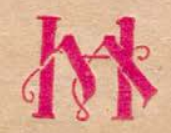

-RAGREB, 1916.

The front cover of the first edition of Priče iz davnine [Tales of Long Ago] by Ivana Brlić-Mažuranić (1916).

Prednja strana korica prvoga izdanja Priča iz davnine Ivane Brlić-Mažuranić (1916). 